will also be stored and analysed by computers, thus making possible the presentation of data at any appropriate level of use.

The development of a forest land classification system will commence immediately. Many government, industry and university foresters will be involved. At the present time other sectors of the inventory have completed much of the groundwork necessary to conduct their portions of the program. Co-operation must be the byword if foresters are to assume their responsibility in the rapid development of a classification system. In the future it is entirely possible that the forest land classification system may be extended in its use to complete an inventory of the entire productive forest area of Canada.

A. W. BLYTH

Seminar On Air Photo Interpretation In The Development Of Canada

Held in Camsell Hall, 588 Booth Street, Ottawa, October 21, 22 and 23, 1963, under the sponsorship of The Interdepartmental Committee on Air Surveys.

This meeting was designed primarily as a discussion of Canadian use of air photography in fields other than topographic mapping. Only two non-Canadian speakers were in attendance: Dr A. P. A. Vink, Director, Department of Natural Resources, International Training Centre for Aerial Survey, Delfte, The Netherlands and Dr. W. A. Fischer, U.S. Geological Survey, Washington, D.C. who, incidentally, is the only nominee for 1964 presidency of the American Society of Photogrammetry.

The emphasis of the meeting was on soil identification as it affected the civil engineers, the geographers, the agriculturists and the foresters. But though this meeting was not designed as a technical gathering of experts the wide variety of topics gave a change of pace and a fair idea of what might be expected in the future.

Dr. Jack Mollard, J. D. Mollard and Associates, Regina, Saskatchewan opened the symposium with a short review of the field. He was followed by Dr. A. P. A. Vink who described the methods of training at Delfte, Netherlands, and one or two of the projects they had undertaken. Emphasis at Delfte is on tropical forestry problems rather than those of northern areas. Of particular interest is that K.L.M. do all of the air photography in the Netherlands. Dr. Vink explained that the prices had to be reasonable or it would be cheaper to use ground methods yet lack of competition meant that there was no disastrous underbidding.

Mr. Sen Mathur of the Ontario Department of Highways described how they used air photographs for route planning and soil surveys. He emphasized the advantages of colour photography in this field.

Then Mr. R. M. Higgs of the Federal Department of Public Works described how they used air photographs for highway location, property acquisition, traffic information and construction.

Dr. John A. Pihlainen told of the formation of permafrost, its effect on engineering projects and how to identify it on air photography. Dr. Pihlainen did not tell how to identify it under forest, explaining that this, so far, was an art, not a science. 
Then Mr. Nicholas Lee explained the use of air photography in identifying ground water.

The next day concentrated on Geography and Geology. Mr. R. F. Tomlinson, Spartan Air Services described the possibilities of air photography for land use planning, a much discussed topic in these days of P.F.R.A. and A.R.D.A.

Dr. D. K. Erb, University of Waterloo, carried the topic a step farther to urban planning including traffic control, and Mr. J. K. Faser emphasized the value of airphotography for rural planning.

Though apparently divorced from forestry the soil study approach used by these gentlemen was as applicable to forestry as to land use studies of settled areas.

In the afternoon Dr. D. T. Anderson of the Geological Survey, Ottawa, went into the subject of colour air photography for geological studies. He had used many types of colour film and was convinced of their advantages. He stated that while the human eye can discern 100-200 tones of black and grey it can recognize about 200,000 colour distinctions. Its only major drawback was cost.

Dr. Harcourt Cameron, Professor of Geology, Acadia University, Wolfville, N.S. told us of the possibilities of "Tiros" and other small scale photography for tide studies, ice movement studies and the study of primary geological formations which can be detected much more easily when very large areas can be examined stereoscopically in one set of photographs.

The final speaker of the day was Dr. W. A. Fischer of the U.S. Geological Survey. Dr. Fischer described the use of non-visible rays in aerial studies of the earth under the heading of "Parameters of Remote Sensing". It was stimulating to hear of the use of ultra-violet and infra-red sensing for geological and water resource studies. Some of his Hawaiian studies were of particular interest. Infra-red sensing studies placed over panchromatic pictures showed four areas warmer than the surrounding territory. Volcanoes have developed on three of these and they are waiting to see whether the fourth will similarily erupt. The detection of possible volcanic outbreaks some months in advance could mean tremendous savings in life and property. They also detected underwater springs near the seacoast by the temperature differentials. We may be using infra-red sensing to locate permafrost and classify forest sites.

On the last day Mr. Lee Munn, P.F.R.A., Regina, Saskatchewan gave a paper on the uses of air photography for agricultural studies covering such diverse fields as soil classification, irrigation studies and ground water studies.

Then Mr. J. B. Springer, James MacLaren Company, read a paper by W. G. E. Brown on forest site classification from air photography. Mr. Brown was in Kenya but Mr. Springer ably covered questions on the subject.

Finally Dr. P. J. B. Duffy, Federal Forest Research Branch, Calgary described how he had prepared air photo volume tables for Alberta lodgepolepine. In addition Dr. Duffy described some of the early work of Mr. G. S. Andrews and others in British Columbia. British Columbia seems so distant to many of us in the east that we are apt to forget the important work being done there. 
This short description cannot do justice to either the papers or the spirited discussions. It is expected that copies of the report will be available for purchase later. If this does not prove practical, abstracts will undoubtedly be prepared.

The only valid criticism of the Seminar was that too many fields were covered preventing detailed studies in any one. This had been fully realized by the Committee and it is hoped that succeeding meetings of this type will be sponsored by other groups which will permit specialization. It is of particular note that difficult as it must have been for members of the Surveys and Mapping Branch to keep from discussing their own field, this subject was never once mentioned by any member of that organization.

J. M. Robinson

\section{Society of AMERICAN Foresters Elects OfFICERS}

Philip A. Briegleb of Portland, Ore., was elected December 7 as president of the Society of American Foresters for the two-year term 1964-1965. He succeeds Paul M. Dunn of New York City who was not a candidate for reelection.

Mr. Briegleb is director of the Pacific Northwest Forest and Range Experiment Station, a research unit of the Forest Service, U.S. Department of Agriculture. On graduation from the New York State College of Forestry at Syracuse University, he joined the U.S. Forest Service in 1929. During his forestry career, which has been largely in research, he has been director also of the Central States Forest Experiment Station, Columbus, Ohio; and of the Southern Forest Experiment Station a New Orleans.

B. E. Allen of Savannah, Ga., was reelected vice president of the Society. $\mathrm{He}$ is manager of the Woodlands Division of Union Bag-Camp Paper Corporation. A forestry graduate of The University of Michigan, he has been on the forestry staff of the corporation since 1943 and manager of its Woodlands Division since 1958.

\section{Association of British Columbia Foresters}

Raymond R. Lejeune, i/c Forest Entomology and Pathology Laboratory, Canada Department of Forestry, Victoria, was elected President of the Association of British Columbia Foresters at the Sixteenth Annual Meeting held in Victoria on February 7, 1964.

Mr. Lejeune succeeds Lawrence A. deGrace, Manager, Industrial Forestry Service Ltd., Prince George, who becomes Past-President.

Vice-President is Robert S. Wood, Woods Manager, Western Plywoods Co. Ltd., Cariboo Division, Quesnel.

Others re-elected to Council are Nicholas V. Mason, Forester i/c Management, B.C. Forest Service, Kamloops; and W. Edward L. Young, i/c Surveys \& Inventory Division, B.C. Forest Service, Victoria.

Newly elected Councillors are:

Robert E. Breadon, Director, U.B.C. Research Forest, Haney.

W. Stanley Hepher, Chief Forester, Alaska Pine \& Cellulose Ltd., and L. William W. Lehrle, Ass't. District Forester, Prince Rupert. F. M. Knapp, Professor Emeritus, Faculty of Forestry, U.B.C. was re-appointed Registrar. 